Vol. 5, No. 3-4, 2019

Petro Zozulia ${ }^{1}$, Oleg Polishchuk ${ }^{2}$, Nazar Kostyuk ${ }^{3}$, Andriy Polishchuk ${ }^{4}$

1. Department of machines and apparatus, electrical and energy systems, Khmelnytskyi National University, Ukraine, Khmelnytskyi, Institutska Street 11, E-mail: zozulia_petro@ukr.net, ORCID 0000-0003-1276-2793

2. Department of machines and apparatus, electrical and energy systems, Khmelnytskyi National University, Ukraine, Khmelnytskyi, Institutska Street 11, E-mail: opolishchuk71@gmail.com, ORCID 0000-0002-9764-8561

3. Department of Mechanical Engineering Technology, Khmelnytskyi National University,

Ukraine, Khmelnytskyi, Institutska Street 11, E-mail: nazkost92@gmail.com, ORCID 0000-0001-6223-6412

4. Department of machines and apparatus, electrical and energy systems, Khmelnytskyi National University, Ukraine, Khmelnytskyi, Institutska Street 11, E-mail: andrepol215@gmail.com, ORCID 0000-0001-7887-7169

\title{
DEVELOPMENT AND INVESTIGATION OF DEVICE FOR PROCESSING POLYMER MATERIALS BY 3D-PRINTING METHOD
}

Received: December 10, 2019 / Revised: December 27, 2019 / Accepted: December 28, 2019

\section{(O) Zozulia P., Polishchuk O., Kostyuk N., Polishchuk A., 2019}

\begin{abstract}
The analysis of the current state of $3 d$ industry and prospects for its future. In the work, calculations were made and graphs of dependence were obtained, which influence the work of the auger and the installation itself. A new method of printing parts with polymer granules is described and the principle of operation of the equipment used is described. The picture of the working installation with the main components and the method of its attachment on a 3D printer is presented. The heating modes of the extruder itself are simulated and a thermal diagram of the device is shown, which accurately displays the temperature distribution across the sections.
\end{abstract}

Keywords: 3D printer, 3D printing, polymer materials, printing, granules, device, auger, heating mode.

\section{Introduction}

Additive technologies are one of the major global trends mentioned in the context of the new industrial revolution. The annual growth of this market, which is not really formed yet and has no clear boundaries, ranges from $20-30 \%$. As is known, there are several methods for layer-by-layer extensions, but they are all derivatives of additive product manufacturing technology. No matter what method used, the creation of the product is carried out by layer-by-layer raw materials. At the output are details of complex geometric shape, which are made in a short time [1].

Modern products are characterized by the complexity of the design, the presence of a large number of parts and components. Even the same footwear, especially of a sporty type, has a complex geometric shape, including active elements in the form of tubes, plates, springs and other parts that increase its performance. Such details are intended for absorption of shock loads arising during various physical exercises, jogging, jumps, and also promote repulsion that allows to improve performance of sportsmen in different kinds of sports. These elements can be structurally designed as a single unit with the sole or in the form of various inserts - polymeric or metal [2].

\section{Problem statement}

Today, the use of 3D printers in mass production is limited by the high cost of the equipment and the length of the manufacturing process. Three-dimensional printing technology can be used in the production of small-scale and individual products, so it is impractical to manufacture high-value equipment [3].

3D printing is increasingly used in various areas of our lives. With the growth of production of polymeric materials, their share in waste is steadily increasing, and the issue of recycling is an integral part of the disposal of human waste. Modern polymeric materials based on different plastics, fibers and elastomers, used in different directions, light and shoe industry are no exception. 
With the introduction of the latest technology in the industry, widely used materials with specific properties. For their processing it is necessary to create an extruder with special thermal modes, geometric parameters and to define a number of parameters that will allow to improve productivity, process efficiency. Therefore, the question of polymer processing is relevant today, and any research in this area is an urgent task.

\section{Analysis of recent research and publications}

Since 2003, there has been a significant increase in sales of 3D printers. In addition, their value has significantly decreased and their scope has expanded. In many sectors of the economy, the practical use of 3D printing is no longer in doubt. Examples include: medicine, engineering, radio and electronics, architecture, automotive, and more. Using 3D printers, you can print furniture, music instruments, vehicles, food, homes, and even living human organs and tissues, etc. [4], [5].

Analyzing the use of 3D printers in various industries, we can conclude that the greatest potential 3D printers have in the production of industrial products. Therefore, 3D printing has the potential to be used in light industry. 3D printers with 3D printing technology are gradually embracing the clothing and footwear industry. 3D printing technology also allows several different materials to be used for the manufacture of a single item of light industry. This approach solves the problems associated with the strength and elasticity of manufactured products.

There are many publications dedicated to 3D printing and 3D printers. From them it follows that the raw materials for the manufacture of parts and products are polymeric materials in the form of bars of different diameters [6].

\section{Objectives and Problems of Research}

In [5] the analysis and systematization of modern technologies of 3D-printing and 3D-printers is carried out. A generalized classification of 3D printers has been developed that gives a complete picture and a description of each type, purpose and so on. This classification also introduced for the first time a new type of $3 \mathrm{D}$ printing, namely $3 \mathrm{D}$ printing by polymer pellets, which in the rapidly evolving industry will become competitive with other types of 3D printing and consumables.

One of the main advantages of this type of printer is the ability to re-print parts with pellets from waste that were obtained during pre-printing, and you can also reduce the cost of the filament using recycled materials. Thus, it is unrealistic to obtain an equal diameter of the bars from the secondary raw material for the simple reason that the properties of the melt will be heterogeneous by weight, hence the uneven pressure in the industrial extruder, the uneven plasticity of the melt and its shrinkage. Accordingly, during printing such a bar will behave quite unpredictably. During the first stage of processing the original polymer and the first life of the polymer chain, irreversible changes are caused by chemical influences, thermal, heat and photo-oxidative degradation, which leads to the appearance of active groups. These groups are capable of triggering oxidation reactions in subsequent modifications. Accordingly, the smaller the number of alterations, the better the material and as a result, it will affect the quality of the future work piece or product.

In order to develop a 3D printer for the manufacture of light industrial parts and products using pellets as feedstock, the following tasks must be solved:

- to carry out calculations and get schedules of dependencies of the work of the auger;

- to make equipment for further experimental studies;

- to obtain a thermal diagram with a further definition of the modes of heating the extruder in its working areas.

\section{Main material presentation}

Pellet printers. As a result, the material is also squeezed out of the heating element, as in FDM technology. This similarity ends. The technology of printing granules is as follows. Instead of the finished rod, which is mainly used for printing, polymer pellets are used which are filled into the hopper or loading area. The raw material is then fed by a rotating auger (Fig. 1) into the melt heating zone for further melting. 
To ensure the necessary movement of the material, the conditions of moving the solid material out of the loading area and filling the inter-turn space in the auger are of great importance extrusion.

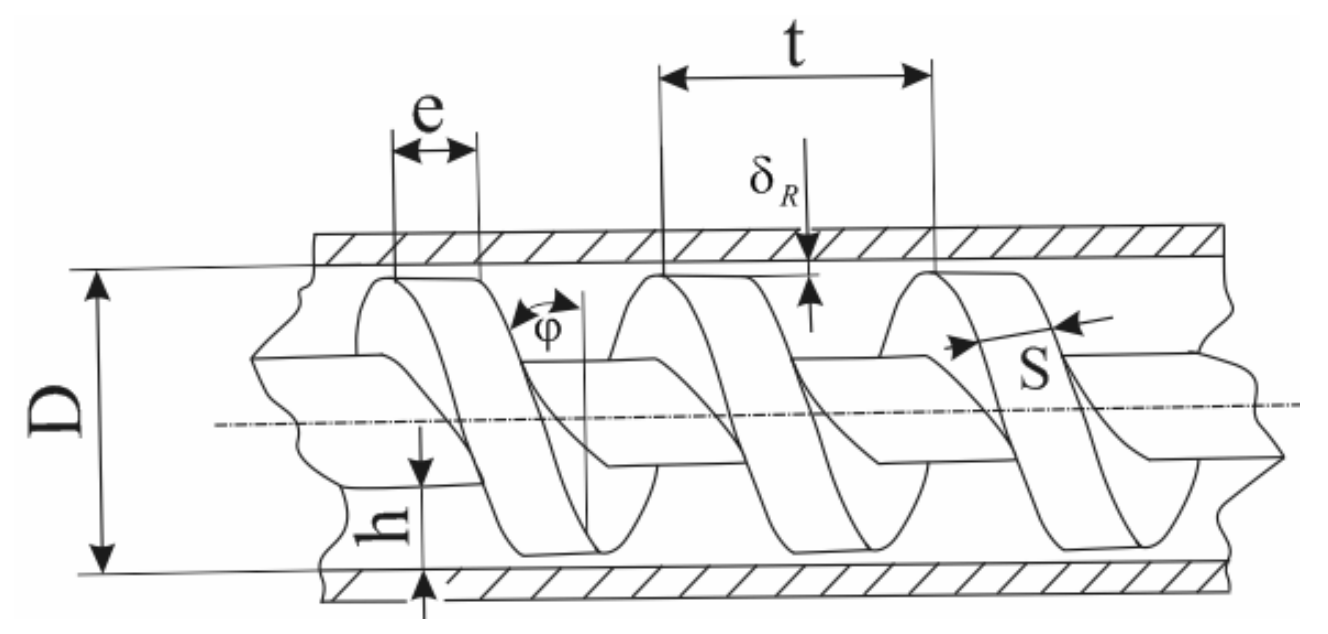

Fig. 1. Designation of the basic parameters of the screw: $\mathrm{D}-$ the diameter of the screw channel; $\mathrm{e}-$ axial wall thickness; $\mathrm{S}$ - the normal wall thickness of the screw channel; $\mathrm{h}$ - the depth of the screw channel; $\mathrm{t}-$ the pitch of the helical channel; $\delta_{R}$ - radial clearance between the inner diameter of the housing and the outer diameter of the screw cutter comb; $\varphi$ - the angle of lift of the screw cutting

Preparation of the polymer material for molding, plasticization, homogenization and feed into the head is due to the rotating auger in the extruder cylinder. Depending on the type of polymers, technological modes of processing, screws of different types are used. Two types of screws are used for processing polymeric masses: with variable depth of spiral channel and with variable pitch.

Loading the installation with a polymeric material for extrusion, fed into the hopper, may be in the form of powder, granules and small plates. One of the main advantages of the developed installation is the ability to re-print parts by pellets from waste that were obtained during the previous printing (Fig. 2). The use of recyclable leads to cheaper products. At first glance, FDM printing technology may seem waste less, but there may be a significant waste of material that goes into the process of selecting the optimum print mode for a particular model.

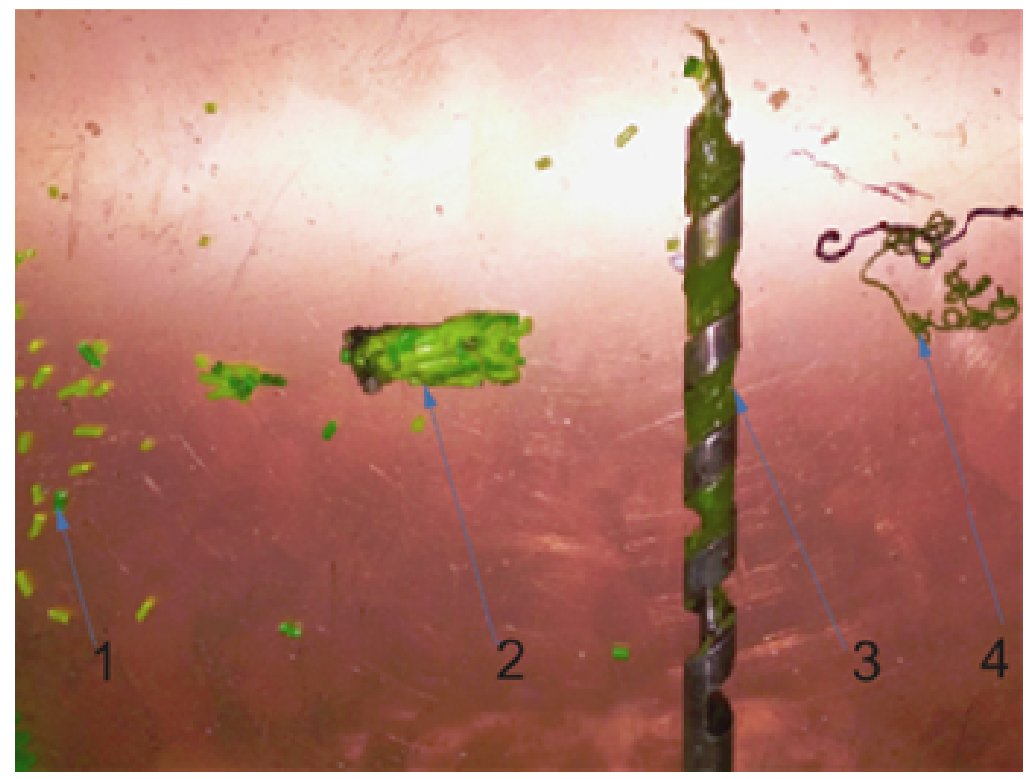

Fig. 2. The working body of the device and the stages of transformation of the polymer parts: 1 - polymer particles; 2 - the beginning of the stage of adhesion and melting of the polymer particles into a solid body; 3 - filling of the inter-turn space of the working auger during operation, the stage of homogenization of the polymer parts into one unit; 4 - source material after extrusion 
Fig. 2 shows the steps of converting the polymer granules that occur during printing. For the first time, a complete analysis of the solids displacement in a traditional single-screw extruder was performed in [7]. The length of the tube should be large enough for the pushing force resulting from the longitudinal motion to allow the polymer to move into the melting zone [3].

Pellet-based printing is ideal for those who want to combine additive and subtractive manufacturing techniques when the part can be quickly printed on a 3D printer using pellets. Currently, rod extruders are quite widely used, but in the main these devices have a high cost and a long process of making the bar itself, which is unacceptable in our competitive environment. Therefore, the calculations of the influence of the parameter were carried out and the graphs of dependence (Figs. 3, 4) were obtained, which influence the work of the auger and the installation itself [8].
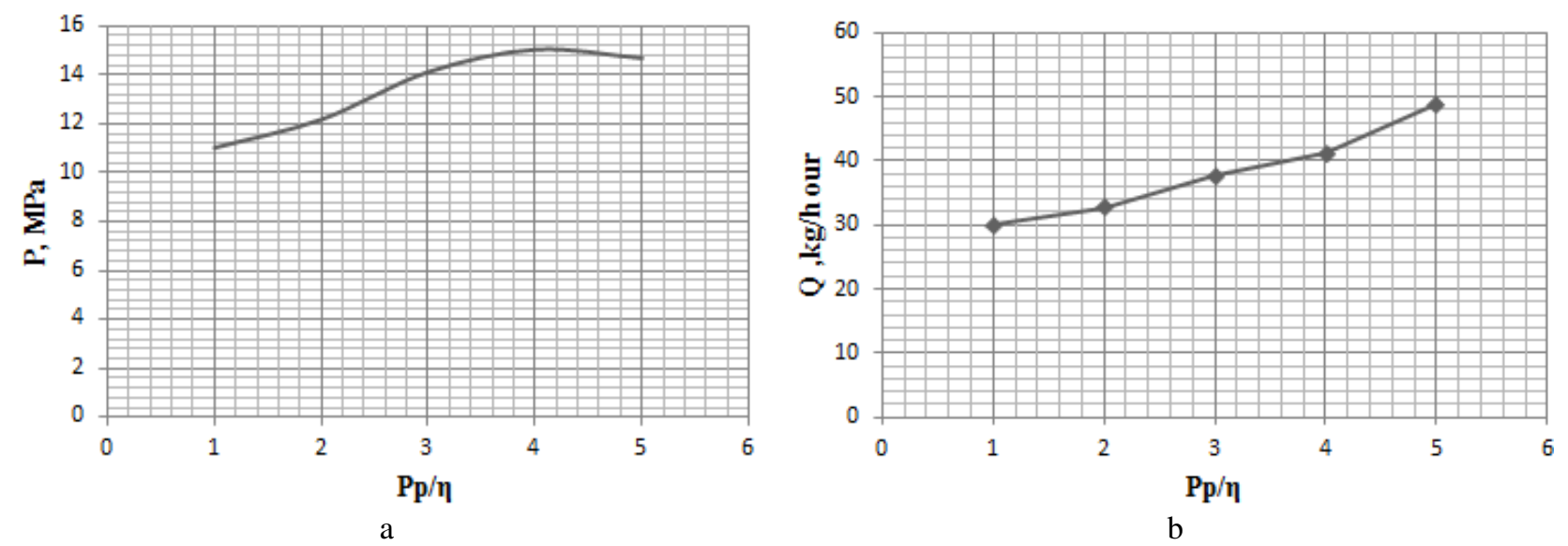

Fig. 3. Dependency graphs: $a$ - pressure $P$ on the density / shear rate; $b$ - performance of the screw on the density / shear rate

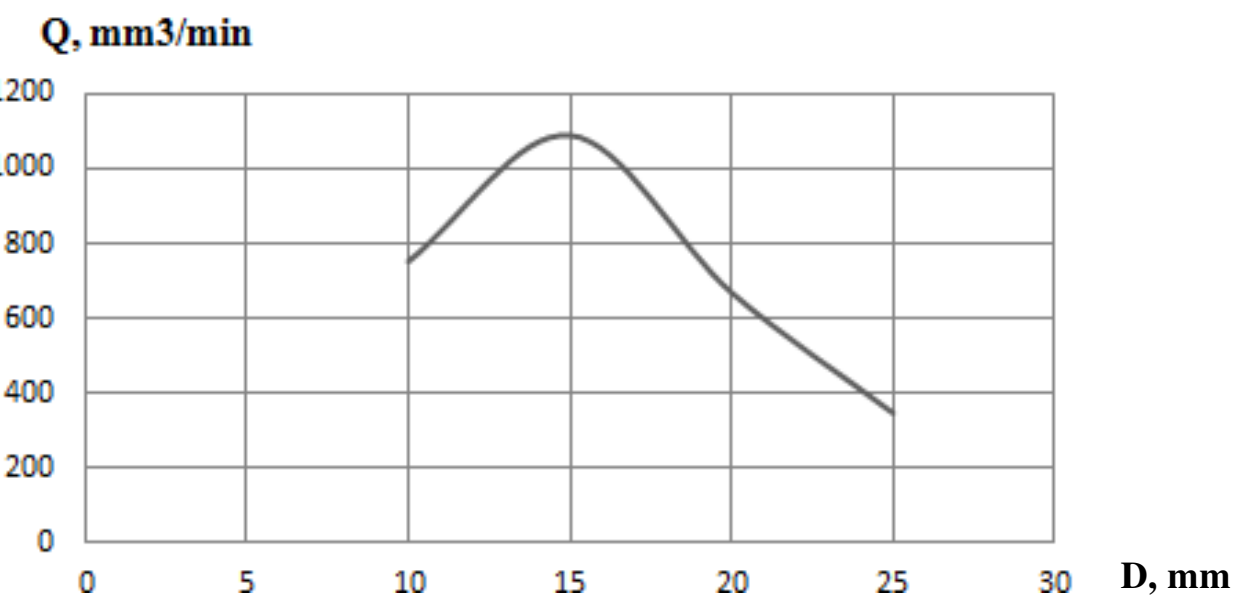

Fig. 4. Dependency graph of the performance of process $Q$ on the diameter of the screw D

The trend is promising and even more so, experts representing construction companies, processing companies and the consumer industry are projecting even more demand for granular polymers. These expectations are fully in line with the global trend. But with the increase in the growth of the operation of polymers directly proportional and will increase the amount of waste.

One of the main advantages of the device (Fig. 5) is the ability to re-print parts by pellets from wastes that were obtained during previous printing.

But also in cases of secondary processing of polymers, it is possible to create new material with new properties by adding different impurities, dyes, plasticizers to their composition for the purpose of improving elasticity, plastic deformation, frost resistance, impact resistance and reducing the viscosity for further processing. [9]. The general view of the installation with the device for processing of polymer masses is shown in Fig. 6. 

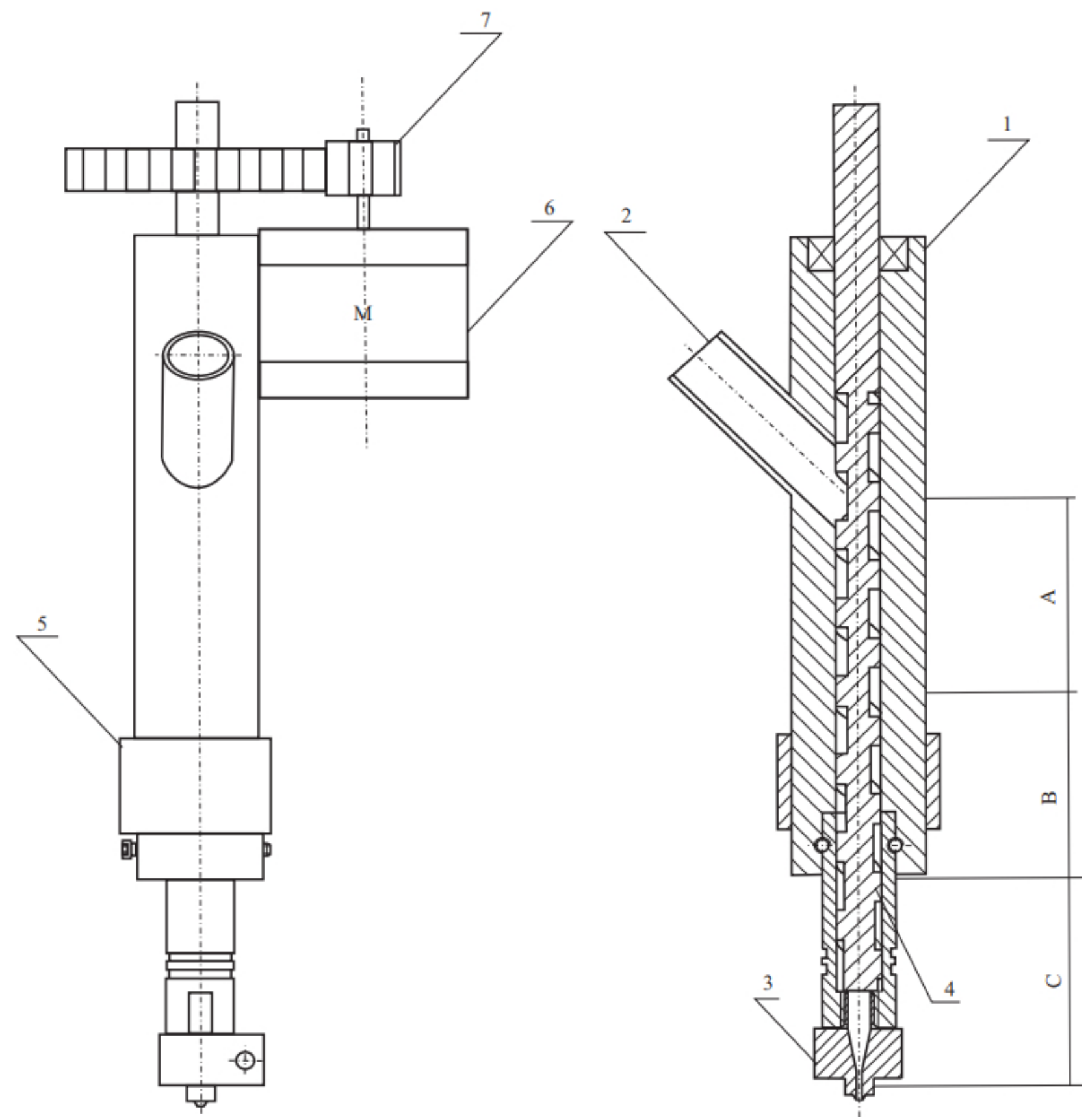

Fig. 5. General view of the device for processing polymeric masses:

1 - case; 2 - loading hole; 3 - formation zone at the outlet; 4 - auger; 5 - heater; 6 - engine; 7 - gearing;

$\mathrm{A}$ - loading zone, $\mathrm{B}$ - melting zone, $\mathrm{C}$ - homogenization zone

During the processing of polymeric materials by the extrusion method, the preheater of the extruder is preheated. Loading the filaments in a cold installation leads to disruption of the process and to problematic situations. This stage is important in terms of its energy consumption and also helps to prevent defects in the final product. With insufficient and uneven heating of the extruder body, the starting material may be of poor quality and its surface will be dark and dull and have various discrepancies in the final product. In order to improve the processing process, namely the efficiency of thermal modes of heating, there is a need for its research through mathematical modeling [10]. Determination of thermal processes occurring during the processing of polymers by extrusion is carried out using special formulas and simulation programs such as SolidWorks Simulation and others.

For the processing of modern polymers with different properties, such equipment is needed, which would meet the required requirements, geometric parameters and thermal modes. 


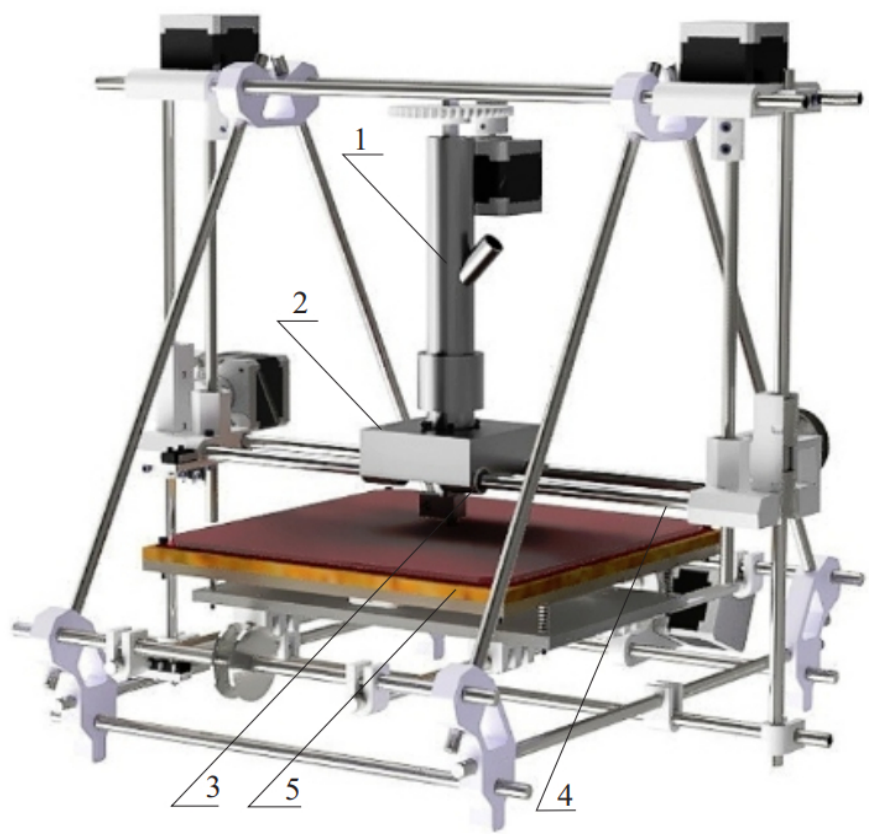

Fig. 6. General view of the installation with a device for processing polymeric masses: 1 - device for processing polymeric masses; 2 - mounting of the extruder installation; 3 - straight-line bearing; 4 - shaft movement of the device; 5 - working surface for cooling the starting material

An important step in the implementation of energy-efficient filament processing equipment by extrusion is to simulate a warm-up process that would allow the extruder to be heated in its working areas. In this regard, there is a need to mathematically simulate the modes of heating the extruder itself before the stage of the direct process of production and study the temperature distribution in the installation, depending on the power of the heaters in different modes. A system of equations and a thermal diagram (Fig. 7) was obtained, which will reproduce the heat and temperature modes of the extruder, which in turn allows us to predict the temperature distribute on of the sites as in the real environment. Fig. 7 shows the temperature distribution of the installation sites.

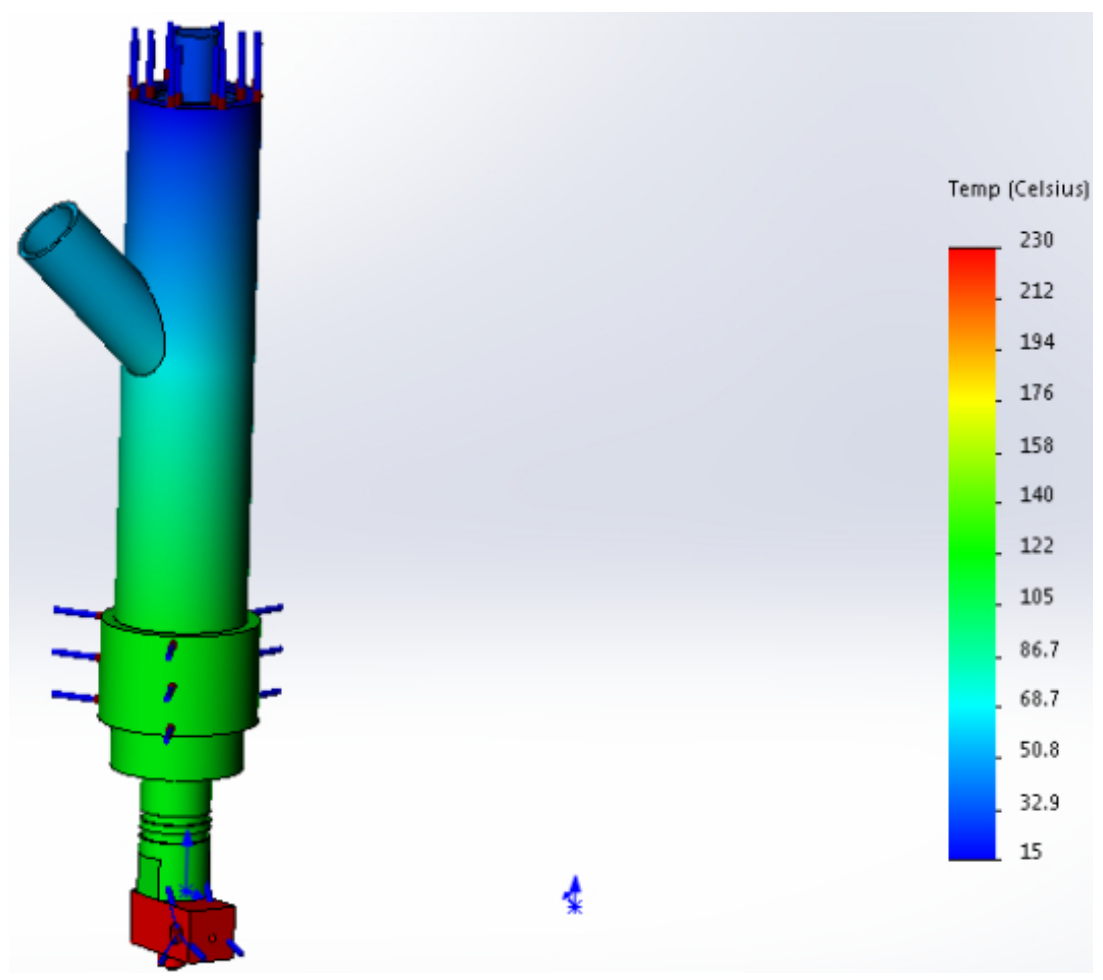

Fig. 7. Picture of temperature distribution over the length of the installation 
From the thermal diagram, we can conclude that the part has sufficient and uniform heating at the set temperatures, thereby providing the necessary plasticization and homogenization of polymeric materials in the installation areas. Fig. 8 presents a graph of the effect of heating temperature on the length of the device.

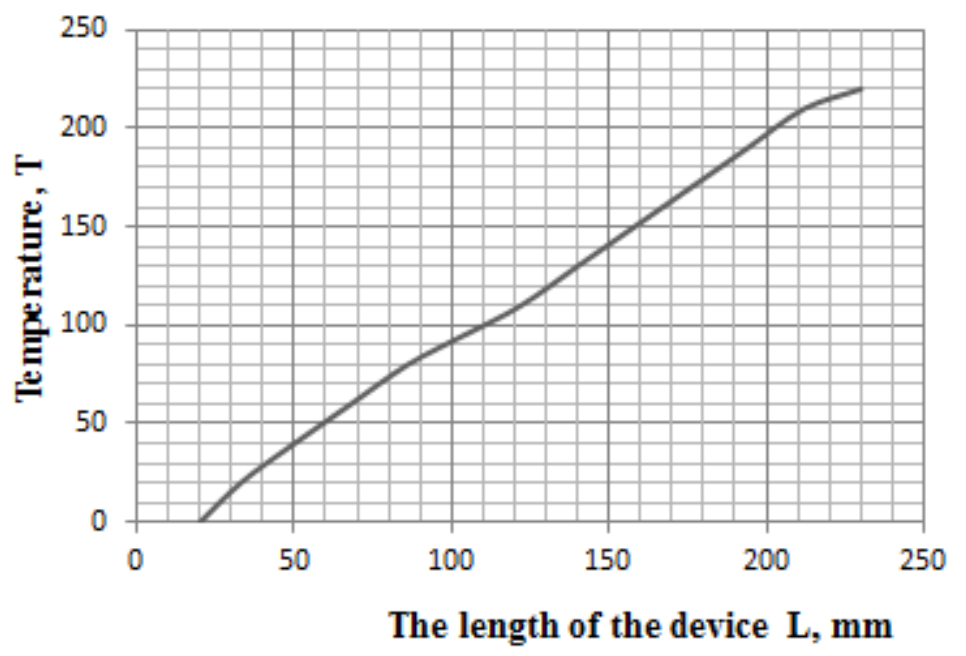

Fig. 8. Graph of temperature distribution over the length of the device

\section{Conclusions}

The analysis of the current state of the $3 \mathrm{~d}$ industry and the prospects for its development in the future is conducted. Based on the work obtained graphs of dependence that affect the work of the auger and the device itself and allow you to estimate how the parameters of the auger depending on the geometric dimensions of the main performance in the processing of thermoplastic materials. The device for processing of polymer masses with special geometric parameters, selected materials of construction and thermal modes is developed and manufactured.

Experimental studies have been carried out on the processing of material using granules.

The thermal diagram of the heating of the unit was obtained with the subsequent determination of the heating of the extruder in its working areas and a graph of temperature distribution with respect to the length of the installation was obtained.

\section{References}

[1] Additivnyye tekhnologii i 3D-pechat': v poiskakh sfer primeneniya [Additive technologies and 3D printing: looking for applications], 2017. [Online]. Available: https://www.forbes.ru/tehnologii/342687-additivnye-tehnologiii-3-d-pechat-v-poiskah-sfer-primeneniya. Accessed on: December 30, 2019. [in Russian].

[2] Yu. V. Bazavluk, "Tovaroznavcha otsinka vzuttya, pravyla ta poryadok yikhn'oho peremishchennya cherez mytnyy kordon Ukrayiny" ["Commodity assessment of footwear, rules and procedure for their movement across the customs border of Ukraine"], M.S. thesis, Department of Commodity Studies and Trade Entrepreneurship, Alfred Nobel University, Ukraine, 2015. [Online]. Available: https://studfile.net/preview/5424245/. Accessed on: December 30, 2019. [in Ukrainian].

[3] P. F. Zozulia, O. S. Polishchuk, V. S. Neimak, and A. O. Polishchuk, "Zastosuvannya tekhnolohiyi 3Ddruku u vzuttyeviy promyslovosti" [“Application of 3D printing technology in footwear industry”], Naukovi notatky [Scientific notes], no. 63, pp. 48-52, 2019. [in Ukrainian].

[4] P. Zozulia, et al., "General classification of 3D printing", in Actual problems of modern science, J. Musial, O. Polishchuk, R. Sorokatji, Eds. Bydgoszcz, Poland: UTP University of Science and Technology, 2017, pp. 413-421.

[5] P. F. Zozulia, O. S. Polishchuk, and A. O. Polishchuk, "Perspektyvy zastosuvannya tekhnolohiyi 3D-druku v lehkiy promyslovosti" ["Prospects for application of 3D printing technology in light industry"], Visnyk Khmel'nyts'koho natsional'noho universytetu [Bulletin of Khmelnytskyi National University], no. 4, pp. 102-104, 2017. [in Ukrainian].

[6] P. F. Zozulia, O. S. Polishchuk, and A. O. Polishchuk, "Uzahal'nena klasyfikatsiya filamentiv dlya 3Ddruku" ["Generalized classification of filaments for 3D printing"], Visnyk Khmel'nyts'koho natsional'noho universytetu [Bulletin of Khmelnytskyi National University], no. 6, pp. 51-59, 2017. [in Ukrainian]. 
[7] N. I. Basov, Yu. V. Kazankov, and V. A. Lyubartovich, Raschet i konstruirovaniye oborudovaniya dlya proizvodstva i pererabotki polimernykh materialov [Calculation and designing of equipment for the production and processing of polymeric materials]. Moscow, Russia: Khimiya Publ., 1986.

[8] P. F. Zozulia, O. S. Polishchuk, and N. O. Kostyuk, "Vliyaniye geometricheskikh parametrov shneka ekstrudera na protsess pererabotki termoplasticheskikh materialov" ["The influence of the geometrical parameters of the extruder screw on the process of processing thermoplastic materials"], Colloquium-journal, no. 3 (55), pp. 45-50, 2020.

[9] I. O. Mikulionok, Obladnannya i protses pererobky termoplastychnykh materialiv z vykorystannyam vtorynnoyi syrovyny [Equipment and process of processing thermoplastic materials using secondary raw materials]. Kyiv, Ukraine: Politekhnika Publ., 2009.

[10] L. B. Radchenko, and V. I. Sivetskyi, Osnovy modelyuvannya ta konstruyuvannya cherv'yachnykh ekstruderiv [Fundamentals of modeling and designing of worm extruders]. Kyiv, Ukraine: Politekhnika Publ., 2002. 